\title{
Utilization of Mobile Phones for Agricultural Purposes by Farmers in Itu Area, Nigeria
}

\author{
Asa, U.A. \\ Department of Agricultural Economics and Extension, \\ University of Uyo, Uyo, Akwa Ibom State, Nigeria. \\ Uwem, $C$. A. \\ Department of Agricultural Economics and Extension, \\ University of Uyo,Uyo, Akwa Ibom State, Nigeria
}

doi: 10.19044/esj.2017.v13n19p395 URL:http://dx.doi.org/10.19044/esj.2017.v13n19p395

\begin{abstract}
The study ascertained the agricultural purposes mobile phones are used for by farmers in Itu Local Government Area of Akwa Ibom State, Nigeria. Data were obtained from 150 farmers using a multi-stage sampling procedure, and analysed using descriptive statistics. Findings reveal that the mean age of the farmers was 49 years; their average monthly income was $\$ 30,133.83$; $59.5 \%$ of them were females; $97.3 \%$ of the respondents were functionally literate; the average years of farming experience of the respondents was 12 years; and their average household size comprised six persons. Majority of the respondents $(98.7 \%$ ) had access to mobile phones in the study area and majority of them (90.5\%) actually owned mobile phones. Getting information from fellow farmers, marketing of produce, accessing inputs for farming, getting agricultural information from radio and the internet, and accessing extension services were the major agricultural uses of mobile phones by farmers in the study area. It is recommended that agricultural extension agencies in Akwa Ibom State focus their attention on these identified agricultural uses of mobile phones to ensure increasing the effectiveness oftheir extension efforts.
\end{abstract}

Keywords: Mobile phones, access, ownership, agricultural uses, Nigeria

\section{Introduction}

Information and communication technologies (ICTs) are the best hope in developing countries to accelerate their development process, and mobile phones are one of the most exciting forms of ICTs particularly in the context of these developing countries (Nyamba and Mlozi, 2012). Mobile phones connect individual to individuals, information, markets and services 
(Aker and Mbiti, 2010), and are becoming increasingly important to agrobased entrepreneurs as aninfrastructural device for improving efficiency of agriculture markets, promoting investment and contributing to empowerment. Mobile phones positively affect rural livelihood outcomes when used in the context of market-oriented farming with supportive ICT regulations and policies, and adequate infrastructure (Mutunga and Waema, 2016). They provide exciting new ways through which extension workers can reach farmers in rural areas that have in the past been very difficult to contact, particularly in developing countries like Nigeria (Haruna et al., 2013).

Rural farmers in developing countries have reported a number of benefits resulting from mobile phone use in agricultural businesses (Martin and Abbott, 2010). Of these, elimination of travel costs, saving of time and market access rise to the top positions. Mobile phones lead to observable increases in "contacts and opportunities", "market access" and increases in "efficiency resulting in greater output". Mobile phone, according to Chhacchar and Hassan (2013), saves energy and time of farmers, and ultimately improves their income. It provides an opportunity tofarmers to communicate directlywith market brokers and consumers for selling their products at good prices. Even though mobile phones are widely used by farmers in Akwa Ibom State (Asa, 2015), there is a dearth of information on the agricultural uses of mobile phones by these farmers. This study attempted to fill this research gap by focusing on determining the agricultural uses of mobile phones in Itu Local Government Area of Akwa Ibom State, Nigeria. Itu Local Government Area is basically an agrarian society hence its choice for this study. Specifically, the study examined the socio-economic characteristics of farmers in Itu Local Government Area, assessed their levels of access/ownership of mobile phones, and determined the agricultural uses of mobile phones by farmers in the study area.

\section{Methodology}

The study was conducted in Itu Local Government Area of Akwa Ibom State, Nigeria. The Local Government Area lies between $6^{\circ} 4 "$ and $6^{\circ}$ 20" North latitudes and $9^{\circ} 30^{\prime \prime}$ and $5^{\circ} 47^{\prime \prime}$ East longitudes (Asa and Inyang, 2016); and has a total population of 127,856 (National Population Commission, 2006). Itu Local Government Area occupies a total land mass of approximately $606.10 \mathrm{~km}^{2}$ and has two major seasons - the rainy season (April to October) and the dry season (November to March). A multi-stage sampling procedure was used to select the respondents for the study. The first stage involved the random selection of 10 villages out of the 79 villages in Itu Local Government Area. The second stage involved the purposive selection of 15 farming households out of each of the selected villages. 
Purposive selection was used to ensure that only farming households in the selected villages were used for the study. The third stage of the multi-stage sampling procedure involved the purposive selection of active farmers in the farming households. Furthermore, one active farmer from each of the fifteen farming households was randomly selected for the study thereby resulting in a total sample size of 150 .

The socio-economic characteristics of farmers in Itu Local Government Area as well as their levels of access/ownership of mobile phones were analysed using descriptive statistics such as frequencies, percentages and means. In order to ascertain the agricultural uses of mobile phones by the farmers, the respondents were requested to indicate whether they use mobile phones for six agricultural practices identified through literature. Their responses were captured with a 3-point rating scale with nominal values assigned topoints in the scale as follows: Never $=0$, Rarely $=$ 1 , and Often $=2$. Mean scores were computed for each of the six items in the scale. A critical mean score of 1.00 served as the cut-off point between major and minor agricultural use of mobilephones by the respondents.

\section{Results and Discussion}

Socio-economic characteristics of farmers in Itu Local Government Area: Table 1 shows the distribution of farmers in Itu Local Government Area of Akwa Ibom State, Nigeria by socio-economic characteristics. Data from the Table reveals that more than half of the respondents (59.3\%) were females which agrees with Akpabio (2005) who reported that most farmers in Akwa Ibom State are females. The mean age of the respondents is 49 years which is in concordance with Asa (2008) who reported that majority of farmers in Akwa Ibom State are below 55 years. Majority of the respondents (86.7\%) are married and $97.3 \%$ are functionally literate. The finding reveals a high level of literacy among the respondents corroborating Asa and Daniel (2015) who reported such similar finding about the literacy level of farmers in Akwa Ibom State. Asa and Ebong (2016) also reported a high level of literacy among farmers in Akwa Ibom State. The high level of literacy of the farmers has a bearing on the efficient use of the features and applications of mobile phones. The average household size of the respondents comprised six persons while their average monthly income is $¥ 30,133.83$ which is relatively low and agrees with Asa and Solomon (2010) who reported a low level of income among rural dwellers (who are mostly famers) in Akwa Ibom State. The average years of farming experience of the respondents is 13 years; and majority of the farmers $(59.3 \%)$ had access to extension services available in the study area. 
Table 1: Socio-economic characteristics of rural dwellers in Akwa Ibom State, Nigeria

\begin{tabular}{|c|c|c|c|}
\hline $\begin{array}{c}\text { Socio-economic } \\
\text { Mean } \\
\text { characteristics }\end{array}$ & Categories & $\begin{array}{l}\text { Frequency } \\
(n=150)\end{array}$ & Percentage \\
\hline \multirow[t]{2}{*}{ Sex } & Male & 61 & 40.7 \\
\hline & Female & 89 & 59.3 \\
\hline \multirow[t]{4}{*}{ Age } & $21-40$ years & 24 & 15.0 \\
\hline & & & \\
\hline & $41-60$ years & 61 & 38.1 \\
\hline & $61-80$ years & 54 & 33.8 \\
\hline \multirow[t]{2}{*}{ Marital status } & Single & 20 & 13.3 \\
\hline & Married & 130 & 86.7 \\
\hline \multirow[t]{4}{*}{ Educational status } & No formal education & 4 & 2.7 \\
\hline & Primary education & 29 & 19.3 \\
\hline & Secondary education & 70 & 46.7 \\
\hline & Tertiary education & 47 & 31.3 \\
\hline \multirow{3}{*}{$\begin{array}{c}\text { Household size } \\
6\end{array}$} & $1-5$ person(s) & 61 & 40.7 \\
\hline & 6-10 persons & 78 & 52.0 \\
\hline & $11-15$ persons & 11 & 7.3 \\
\hline \multirow{4}{*}{$\begin{array}{l}\text { Monthly income (in Naira) } \\
30,133.83\end{array}$} & $10,001-30,000$ & 93 & 62.0 \\
\hline & $30,001-50,000$ & 43 & 28.7 \\
\hline & $50,001-70,000$ & 9 & 6.0 \\
\hline & $70,001-90,000$ & 5 & 3.3 \\
\hline \multirow{3}{*}{$\begin{array}{l}\text { Years of farming experience } \\
13\end{array}$} & $1-20$ year(s) & 131 & 87.3 \\
\hline & $21-40$ years & 18 & 12.0 \\
\hline & $41-60$ years & 1 & 0.7 \\
\hline \multirow[t]{2}{*}{ Access to extension services } & Yes & 89 & 59.3 \\
\hline & No & 61 & 40.7 \\
\hline
\end{tabular}

Note: Naira ( is the Nigerian currency and 1.00 US Dollar is equal to 315.25 Nigerian Naira as at May 12, 2017

Source: Field survey, 2016

Levels of access/ownership of mobile phones by farmers in Itu Local Government Area: Table 2 reveals that majority of the respondents (98.7\%) had access to mobile phones in the study area. The finding agrees with Robert (2014) who also reported a high level of access to mobile phones among farmers in Itu Local Government Area of Akwa Ibom State, Nigeria in a previous study. Aker and Mbiti (2010) averred that access to mobile phones in sub-Saharan Africa has increased drastically over the years. James and Versteeg (2007) noted that in rural communities of Africa, such as Itu Local Government Area, it is common to informally share a mobile device between families, partners, friends, or neighbours. The high level of access to mobile phones by farmers in the study area has enhanced the efficient sharing of vital prices and trading information among the 
farmers which has been helping them decide where and what price to sell their produce; it has also reduced transaction and transportation costs for the farmers. Agricultural information are often shared by the farmers via text messages and voice calls. Abraham (2007) reported that the results of using mobile phones for agricultural purposes are increased efficiency, increased yields, reduction in wastage and an overall positive effect on farmers' earning and livelihood.

Table 2: Distribution of respondents based on access to mobile phones

\begin{tabular}{lcc}
\hline Access? & Frequency & Percentage \\
\hline Yes & 148 & 98.7 \\
No & 2 & 1.3 \\
Total & 150 & 100 \\
\hline
\end{tabular}

Source: Field survey, 2016

Out of the 148 respondents that had access to mobile phones as shown in Table 2, $90.5 \%$ of them actually owned the mobile phones they have access to while $9.5 \%$ did not own the mobile phones they have access to. This finding, depicted in Table 3, reveals a high level of ownership of mobile phones among farmers in the study area.. Haruna et al (2013) also reported that most farmers in Nigeria own mobile phones and have found them very effective in sourcing and sending information regarding their farming businesses.

Table 3: Distribution of respondents based on ownership of mobile phones

\begin{tabular}{lll}
\hline Ownership? & Frequency & Percentage \\
\hline Yes & 134 & 90.5 \\
No & 14 & 9.5 \\
Total & 148 & 100 \\
\hline
\end{tabular}

Source: Field survey, 2016

Agricultural uses of mobile phones by farmers in Itu Local Government Area: The agricultural uses of mobile phones by farmers in Itu Local Government Area are shown in Table 4. The Table reveals that the major agricultural uses of mobile phones by the respondents are: getting information from fellow farmers $(\bar{x}=1.61)$, marketing of produce $(\bar{x}=1.50)$, accessing inputs for farming $(\bar{x}=1.47)$, getting agricultural information from radio and Internet $(\bar{x}=1.32)$ and accessing extension services $(\bar{x}=1.24)$. Getting agricultural information from fellow farmers to help make important farming decisions is very common practice among the respondents since they trust the information from fellow farmers than agricultural information from other sources. Abraham (2007) posited that mobile telephony enhances the efficient sharing of agricultural information on weather reports, farming decisions and innovations. With respect to "marketing of produce", mobile 
telecommunications help deliver prices and trading information to both the farmers and other stakeholders in the agricultural sector as reported by Aker (2008). Farmers in Itu Area also use their mobile phones to access inputs such as fertilizer, herbicides, and improved crop varieties from local vendors and governmental agencies. By making calls or sending text messages, such inputs are easily made available to the farmers in their homes/farms at mutually agreed prices. Apart from getting agricultural information from fellow farmers, the respondents also use mobile phones to get agricultural information from the radio and the internet. This is because most mobile phones available in the study area have features of radio and internet services. The high level of education of these farmers (as depicted in Table 1) is a big advantage in efficiently using mobile phones to access agricultural information from the internet. The extension agents of the governmental agencies responsible for providing extension services to farmers in Itu Area, Nigeria often give out their phone numbers to their clientele thereby enhancing increased use of mobile phones to access extension services by the respondents. On the other hand, the minor agricultural use of mobile phones by the respondents is "playing music/videos for entertainment during farming activities" ( $\bar{x}=0.50)$. This minor usage could be due to the need to conserve the battery life of mobile phones by the farmers since steady electric power supply for charging mobile phones is a major challenge to use of mobile phones in rural areas of Akwa Ibom State, including the farming communities in Itu Local Government Area (Asa, 2015).

Table 4: Agricultural uses of mobile phones by farmers in Itu Local Government Area

\begin{tabular}{lll}
\hline Agricultural uses & Mean & Remarks \\
\hline 1.Getting agricultural information from radio and Internet & 1.32 & Major \\
2. Accessing inputs for farming & 1.47 & Major \\
3. Marketing of produce & 1.50 & Major \\
4. Accessing extension services & 1.24 & Major \\
5. Getting information from fellow farmers & 1.61 & Major \\
$\begin{array}{l}\text { 6. Playing music/videos for entertainment during farming } \\
\text { activities }\end{array}$ & 0.50 & Minor \\
\hline
\end{tabular}

Source: Field survey, 2016

\section{Conclusion and Recommendation}

The primary objective of the study was to assess the utilization of mobile phones for agricultural purposes by farmers in Itu Area, Nigeria. Overall findings of the study suggest that majority of farmers in Itu Area, Nigeria have access to/own mobile phones; and, getting information from fellow farmers, marketing of their agricultural produce, accessing inputs for farming, getting agricultural information from the radio and the internet as well as accessing extension services are the major agricultural purposes mobile phones are majorly used for by farmers in the study area. It is 
therefore recommended that agricultural extension agencies in Akwa Ibom State - both Governmental and non-Governmental - focus their attention on these identified agricultural uses of mobile phones in carrying out ICT-based extension services to ensure an increase in effectiveness of extension efforts.

\section{References}

1. Abraham, R. (2007) Mobile phones and economic development: Evidence from the fishing industry in India, Information Technologies and International Development, 4 (1): 5-17

2. Aker, J. C. (2008) Does Digital Divide or Provide? The impact of cell phones on grain markets in Niger, Centre for Global Development Working Paper No. 154. Retrieved from www.cgdev.org/content/publications/detail/894410 on May 13, 2015

3. Aker, J. C. and Mbiti, I. B. (2010). Mobile phones and economic development in Africa. Journal of Economic Perspectives, 24(3): 207 $-232$.

4. Akpabio, I. A. (2005).Human Agriculture: Social Themes in Agricultural Development, Uyo, Nigeria: Abaam Publishing Co. $219 \mathrm{pp}$.

5. Asa, U. A. (2008). Livelihood activities and poverty alleviation among rural women in Akwa Ibom State, Nigeria. Ph.D Thesis, Department of Rural Sociology and Extension, Michael Okpara University of Agriculture, Umudike, Nigeria. 157pp.

6. Asa, U. A. (2015). Constraints to mobile phones utilization by rural dwellers in Akwa Ibom State, Nigeria. International Journal of Information and Communication Technology Research, 5(2): 28 34.

7. Asa, U. A. and Daniel, E. A. (2015). Barriers to contraceptive use among rural farmers in Akwa Ibom State, Nigeria. International Journal of Agricultural Extension and Rural Development Studies, 2(1): $22-29$.

8. Asa, U. A. and Ebong, E. O. (2016). Determinants of food security status of farming households in rural areas of Akwa Ibom State, Nigeria. Indo-American Journal of Agricultural and Veterinary Sciences, 4(2): $1-7$.

9. Asa, U. A. and Inyang, N. D. (2016). Training needs of rural fisherfolks: A case study of Itu Area of Akwa Ibom State, Nigeria. European Journal of Training and Development Studies, 3(1): 35 42.

10. Asa, U. A. and Solomon, V. A. (2010). Gender participation in livelihood activities of rural dwellers in Akwa Ibom State, Nigeria. 
International Journal of Applied Agricultural and Apicultural Research, 6(1\&2): $57-64$.

11. Chhachar, A. R. and Hassan, M. S. (2013). The use of mobilephone among farmers for agricultural development. International Journal of Scientific Research, 2(6): 95 - 98.

12. Haruna, S. K., Jamilu, A. A., Abdullahi, A. Y. and Murtala, G. B. (2013). Ownership and use of mobile phones among farmers in Northern Senatorial Zone of Kaduna State. Journal of Extension, 17(2): $47-54$.

13. James, J. and Versteeg, M. (2007). Mobile phones in Africa: How much do we really know? Social Indicators Research, 84(1): 117126.

14. Martin, B. and Abbott, D. (2010). Development calling: The use of mobile phones in agriculture development in Uganda. Greenlee School of Journalism and Communication, Iowa State University.

15. Mutunga, I. M. and Waema, T. M. (2016). Context of mobile phone use and its effect on smallholder farmers' livelihood outcomes in Kenya. International Journal of ScientificResearch and Innovative Technology, 3(4).

16. National Population Commission (2006). "Population and Housing Census of the Federal Republic of Nigeria," Analytical Report at the National Population Commission, Abuja, Nigeria.

17. Nyamba, S. Y. and Mlozi, M. R. S. (2012). Factors influencing the use of mobile phones in communicating agricultural information: A case of Kilolo District, Iringi, Tanzania. International Journal of Information and Communication Technology Research, 2(7): 558563.

18. Robert, A. P. (2014). Constraints to mobile telephone utilization by rural dwellers in Itu Local Government Area of Akwa Ibom State. Department of Agricultural Economics and Extension, University of Uyo, Uyo. 102pp. 